\title{
UNION SOLIDARITY IN EASTERN AND CENTRAL EUROPE FROM THE EXAMPLE OF POLAND
}

\author{
KATARZYNA BOMBA*
}

\section{INTRODUCTION}

The transformation of formerly communist countries in Central and Eastern Europe (CEE) $)^{1}$ posed a great challenge for trade unions. During the communist period they functioned as mass organisations with a mandate from the state. In 1989/90, the transition from socialism to capitalism required them to restructure to be able to renegotiate working conditions within the social dialogue with the state and with employers. In addition, the CEE countries needed to modernise the legal status of trade unions and transpose European law ahead of planned integration with the European Union. ${ }^{2}$ These two factors put pressure on countries, and directly on trade unions, to adapt to the new environment of a free market, competition, privatisation, globalisation, and small and medium as well as multinational companies. In a very short period of time they needed to build a new model of industrial relations that in Western countries had taken many decades. ${ }^{3}$ That poses the question as to whether the model of industrial relations that appeared in post-communist countries works effectively toward union solidarity. The paper examines this issue using the example of Polish legal regulations given in the wider light of legal positions of trade unions in CEE countries.

DOI: $10.1515 /$ wrlae-2018-0008

* PhD, Assistant professor, Department of Labour Law and Social Security, Faculty of Law and Administration, University of Warmia and Mazury in Olsztyn, Poland, Email: katarzyna.bomba@uwm.edu.pl

${ }^{1}$ The Central and Eastern Europe countries are defined as those acceding to the EU in 2004 (Estonia, Lithuania, Slovenia, Slovakia, Hungary, Czech Republic) and in 2007 (Bulgaria and Romania).

${ }^{2}$ Helmut Kohl, 'Where Do Trade Unions Stand Today In Eastern Europe? Stock-taking After EU Enlargement', Friedrich Ebert Stiftung, International Trade Union Cooperation, Briefing Paper no. 5/2008, 1.

${ }^{3}$ ibid. 


\section{TRADE UNIONS DURING THE COMMUNIST PERIOD}

As a rule, communist countries (e.g. Poland, Hungary) were one-party systems established as a network of party units in different companies. The main idea of the communist governments was to make trade unions "a transmission belt" between the communist party and the people. ${ }^{4}$ To control the activities of companies and the unions it was necessary to establish smaller sections of trade unions and place them at the lowest level of enterprises. ${ }^{5}$ For that reason, in Poland in 1982 (during martial law) all existing trade unions, including NSZZ Solidarność, were liquidated, and the union movements were restored from the bottom to national level. Restoring unions was the result of the popularity of the newly-founded alternative trade union called NSZZ Solidarność and dissolving the former monopoly organisation of the CRZZ (Central Council Trade Unions). New trade unions established at plant level could, from 1983, organize themselves at the national level, and from 1984 they could establish inter-union federations. However, once a trade union acquired its position at enterprise level, it was not interested in transforming the union to a multi-enterprise structure and creating a union based on the trade or sector division. For that reason workers were organised mostly at enterprise level, and multi-enterprise trade unions acted usually in the form of a federation of enterprise-based trade unions. In 1984, a large number (around 100) of the newly-registered sectoral organisations united to form the confederation called OPZZ (All-Polish Alliance of Trade Unions). ${ }^{6}$ However, the trade unions' competences were very restricted. Under communism they had been focused on social matters e.g. holidays and housing, but nothing directly connected with working conditions. The decisions regarding wages, working time and other working conditions were centralized. ${ }^{7}$ Unions did not play an important role in the wage negotiating process determined by the state, nor were they were responsible for job security in the light of the state's goal of full employment. ${ }^{8}$ In that environment the rate of unionization was almost one hundred per cent. In reality trade unions lacked the support of their members who saw them as an instrument of the communist party to recruit party members and manage local political activities.

\footnotetext{
${ }^{4}$ Marek Pliszkiewicz, 'The Development of Industrial Relations in Central and Eastern Europe' in Michał Seweryński (ed), Polish Labour Law and Collective Labour Relations in the Period of Transformation, (Warsaw: Ministry of Labour and Social Policy, 1995) 132. See also Michał Seweryński, 'Trade Unions in the Post-Communist Countries: Regulations, Problems and Prospects' (Winter 1995) 16 Comparative Labour Law Journal 177-230195.

5 Michał Seweryński, 'Toward a New Codification of Polish Labour Law' (2004) 26 Comparative Labour Law and Policy Journal 55-95, 75; Seweryński (n 4) 181.

${ }^{6}$ Kohl (n 2) 1.

${ }^{7}$ Janas Aczel, 'Changes in the role of the trade union in the Hungarian printing industry. A transition from socialism to a market economy' (2005) 27/6 Employee Relations 566-580.

${ }^{8}$ Kohl (n 2) 1.
} 


\section{CURRENT MODEL OF INDUSTRIAL RELATIONS}

Poland was the first among the previously socialist countries where the end of the totalitarian system appeared on the horizon in the early 1980s. ${ }^{9}$ In 1989, NSZZ Solidarność was re-established and in the same year, as a result of the first free election, it formed the government. Both confederations, OPZZ and NSZZ Solidarność, were affected by strong politicisation which led to the polarisation of the union movement. A third, politically neutral confederation, FZZ (Forum of Trade Unions) then appeared, and numerous autonomous and non-affiliated sectoral and company specific unions were founded. Despite the withdrawal from politics of trade unions and their confederations after 2000, and their concentration on trade union activities, they have never regained their previous importance. In Poland the level of membership rates decreased from 33\% to $12 \%$ between 1995 and 2013. It is a common phenomenon in all post-communist countries - in Hungary from $63 \%$ to $12 \%$, in Lithuania the level of unionisation decreased from $20 \%$ to $10 \%$, in Latvia from $28 \%$ to $13 \%$, in the Czech Republic from $46 \%$ to $17 \%$, and in Slovakia from $57 \%$ to $22 \% .{ }^{10}$

Analysing how industrial relations developed in the period of transition from socialism to capitalism allows the challenges confronted by trade unions to be identified.

\section{The structure of enterprises}

Trade unions in Central and Eastern Europe are in crisis following the transformation in 1989 which is caused by changes on the labour market. After the collapse of the socialist economy, with its dominant state-owned entities, the labour market of post-communist countries generally transformed into a multitude of SMEs. These changes had an important influence on the structures of trade unions. Newly-established associations, as well as those which restructured during the transformation period in the CEE countries, broke up the monolithic trade union organisations which previously existed. With the exception of a few countries e.g. the Czech and Slovak Republics, where trade unions restarted with a new ideology and different leaderships, in countries such as Poland or Hungary, where the formation of a new type of trade unions started early, political and ideological aspects were present in their activities at least until the mid-1990s. ${ }^{11}$ This process of change was also related to the internal organisation of the trade unions. They were maintained with their relatively large number of sectoral sub-structures despite persistent losses of members and changed functions. ${ }^{12}$ In the new environment the

\footnotetext{
9 ibid 2.

10 www.worker-participation.eu/National-Industrial-Relations/Across-Europe/TradeUnions2 (Access: 30 of June 2014). To compare a similar trend, but on a smaller scale, we can observe Western countries where the membership range in 1995 was estimated at $31 \%$ and it had decreased in 2013 to $23 \%$.

${ }^{11} \mathrm{Kohl}$ (n 2) 4.

12 Countries marked by highly-developed trade union pluralism are left with an impressive number of sectoral organisations, which does not necessarily ensure greater clout in collective negotiations. However, for example, the internal organisation of Polish Solidarność contrasts with these decentralised structures. There are only sectoral offices at the headquarters with sub-divisions even in the regional sub-centres, unlike the OPZZ with its approx. 100 sectoral branches. Such a profound form of organisation might have seemed
} 
sectoral organisations lost their former functions in social and cultural matters and in leisure time; however, they still retained an important role within independent bargaining policy. ${ }^{13}$

In the new environment the most urgent challenge to meet was to strengthen the union movement through the recruitment of new members of trade unions and to establish new trade unions in non-unionized sectors. In some CEE countries the important obstacle in recruiting new trade union members was the legal exclusion from joining unions ${ }^{14}$ of some employees in micro-businesses, the unemployed or people employed on temporary contracts. That happens, for example, in Lithuania where only the employees of a company can be members of that company's trade union. ${ }^{15}$ In Poland, according to Article $2 \S 1$ TUA, ${ }^{16}$ all employees, regardless of their employment relationship basis, as well as members of agricultural production co-operatives, and individuals who perform work on the basis of an agency contract, if they are not employers, have the right to establish and join trade unions. However, Article $2 \S 2-7$ TUA, indicates several groups of people are entitled to join trade unions only if the statute of the trade union allows for that. Indeed they are deprived of the possibility to create new trade unions. These restrictions refer especially to individuals who perform home based work $(\S 2)$, those who are retired or who have retired for reasons of disability (§ 3), the unemployed (§ 4) etc. In fact, Polish Trade Union Law, based on the principle of the self-governing of trade unions, leaves the requirements to join a trade union to their internal regulations. Therefore, if the statute of a particular trade union allows them to join, they can become trade union members without statutory restrictions. However, it is hard to imagine that in the statutes of trade unions there will be limitations as to the possibility of joining the union.

Another important issue for the level of unionization is the procedure of establishing unions in enterprises where they are under-represented. Trade union representation is the most widespread in those domains of the economy where ex-state owned companies continue to operate, as well as in the public sector, such as healthcare and education. ${ }^{17}$ By contrast, trade unionism is quite rare in the newly-developed private sector, built mostly by small and medium enterprises. However, even in state-owned companies, trade unions are very numerous e.g. there are around 100 trade unions in the railway company in Poland, which reduces their efficiency when acting towards representing the rights and interests of employees.

In many SMEs in Poland where there are fewer than 10 employees, trade unions cannot be established. According to Article 12 TUA a trade

promising had there not been a change during the period of transformation and the heavy decline in membership level. See: Kohl (n 2) 5.

${ }^{13}$ Kohl (n 2) 5.

14 ibid.

${ }^{15}$ Lithuania's Law on Trade Unions stipulates that anyone over the age of 14, including students, the unemployed and people who have retired may join sectoral, local and national trade unions. However, in the case of a company's trade unions there is a limitation to only employees of that company. See: www. eurofound.europa.eu/eiro/2013/10/articles/lt310039.htm (Access: 28 July 2014).

${ }^{16}$ Ustawa o związkach zawodowych z dnia 23 maja 1991 [Trade Union Act - TUA of 23 May 1991], Dz.U. No 55, item 234.

${ }^{17}$ Kohl (n 2) 6. 
union can be established if at least 10 people who are entitled to establish a trade union adopt such a resolution. This threshold is similar to other CCE countries e.g. in Hungary (also 10 people), however, in Lithuania the threshold to establish a trade union is only 3 people. They adopt the statue and appoint three to seven members of the founding committee who are obliged to submit the registration request within 30 days of the founding date. At the moment of registration the trade union acquires legal status, so in that statutory prescribed way, enterprise-based trade unions are established. Multi-enterprise trade unions which were established earlier through the statutory procedure can establish external branches which will be recognized by the TUA as an enterprise-based trade union under their statutes. They are not identical to trade unions, as they represent units of multi-establishment trade union organisations created at enterprise level. ${ }^{18}$ Another feature, characteristic of collective labour law, is that it is based on the principle of trade union pluralism. Polish labour law does not limit the number of trade unions in one enterprise, however, from an amendment in 2003 in Art. 25(1) TUA it makes a union's strength dependent on the number of its members. ${ }^{19}$ Under this provision only an enterprise-based trade union which has at least 10 members who are employees, or persons who work under a cottage work contract with the employer where the trade union is active, is entitled to exercise the rights of an enterprise-based trade union. Every four months the trade union needs to present to the employer the list of its members. Failing to do this will result in the employer not recognising the trade union. ${ }^{20}$ As a

\footnotetext{
${ }^{18}$ Zbigniew Hajn, 'Representation of Employees in Collective Bargaining within the Firm in Poland' in Biruta Lewaszkiewicz-Petrykowska (ed), Presénté au XVIIe Congrés international de droit comparé (Łódź, Wydawnictwo Uniwersytetu Łódzkiego 2006) 124.

${ }^{19}$ Before 2003 there was no interdependence between the factual strength of an enterprisebased trade union and its rights.

${ }^{20}$ Article 25(1) TUA: "1. An organisation enjoys the rights of a work establishment's trade union organisation, provided that it has at least ten members who are: 1) employees or individuals who work under a home working contract with the employer where the organisation is active, or 2) officers referred to in Article 2 item 6 [officers of the Police, Border Guard and Prison Service, firemen of the National Fire Brigades as well as the employees of the Supreme Chamber of Control - $\mathrm{KB}$ ] who are on duty in the unit where the organisation is active. 2. Every quarter, by the tenth day of the month following that quarter, the organisation referred to in section 1 presents information, as of the last day of the quarter, about the total number of members of the organisation, including the number of members referred to in section 1, to the employer or unit commander referred to in section 1 point 2 ". The Polish Constitutional Tribunal in its judgment of 28 September 2006 (Case K 45/04, OJ 2006, No 183, pos. 1363) considered the claim trade unions, if the regulation of Article 25(1) TUA is in accordance with the Article 2 of ILO 87 Convention and Article 31(3) and Article 59(1) of the Polish Constitution. Art. 22 Polish Constitution states: "Any limitation upon the exercise of constitutional freedoms and rights may be imposed only by statute, and only when necessary in a democratic state for the protection of its security or public order, or to protect the natural environment, health or public morals, or the freedom and rights of other persons. Such limitation shall not violate the essence of freedom and rights." Art. $59 \S 1$ of the Polish Constitution says: "The freedom of association in trade unions, socio-occupational organizations of farmers, and in employers' organisations shall be ensured." Art. $59 \S 4$ of the Polish Constitution follows: "The scope of freedom of association in trade unions and in employers' organisations may only be subject to such statutory limitations as are permissible in accordance with international agreements to which the Republic of Poland is a party." The Constitutional Tribunal noticed that Article 2 ILO 87 The convention does not regulate the relationship between the employer and trade union so it is cannot provide a trade union any rights in relation to the employer. Moreover, the State regulating the relation between unions
} 
consequence of that structure of collective relations, the question about the situation of small employers with fewer than 10 employees arises. The Constitutional Tribunal in its Judgment from 28 September $2006^{21}$ said that workers employed by small enterprises must not be deprived of the right of association. It refers to Article 34 TUA which regulates an inter-enterprise trade union which unites the former unionized workers of two or more employers. Under that provision the condition of 10 members being required for the trade union to be recognized by the employer is met when the interenterprise trade union has at least 10 members in total. The regulation of Article 34 TUA is, in some way, a response to the problem of structural changes on the labour market. Its effectiveness may raise some doubts if in practice an inter-enterprise trade union is established only by employees from the same sector of industry which often cooperate with each other. However, as the Polish example shows, the problem does not lie in the structure of an industry based on SMEs, or at least it is not the most important problem.

\section{The role of the state in shaping working conditions}

The low level of unionization may refer to the unsupportive behaviour of employees as an effect of the gradually increasing weakness of trade unions within the labour market. Indeed, two factors have definitely influenced the changing role of trade unions in this sphere: the transition to a market economy and accession to the EU. The battle between trade unions and profitoriented employers has persuaded them to adapt to the new circumstances to be able to renegotiate working conditions through collective bargaining and industrial action at the level of enterprises, multi-enterprises as well as within national tripartite bodies. ${ }^{22}$ Regardless of the gradual liberalisation and deregulation which gave the social partners greater freedom in shaping their bilateral relations, in all the post-communist countries ${ }^{23}$ the State has still played a pivotal role in the tripartite economic and social councils which have extensive regulatory powers in economic and social policy, especially in determining remuneration systems affected by existing minimum wage levels. In Poland the competence of trade unions in the Tripartite Commission is restricted to expressing a non-binding opinion on limited issues. Article 19 TUA states that trade unions have a right to express opinions on the reasonings and drafts of legal acts within the scope covered by the tasks of trade unions. However, it does not apply to the reasoning of the draft of the state budget. The opinion of trade unions does not have a binding character (Article $19 \S 3$ TUA). Because of the limited scope of this paper, the topic of

and employers needs to take into account the justified interests of both sides to keep a balance between the protection of workers' rights and providing effective management of an enterprise. What's more, Article 25(1) TUA does not limit the employees' right to association but it limits the scope of unions' rights due to protecting the justified interests of employers.

${ }^{21}$ Case K 45/04, Dz.U. 2006, No 183, item 1363.

22 The Tripartite Commission for Socio-Economic Matters was established in Poland under the Resolution of the Council of Ministers from 15 February 1994. Currently in Poland, trade unions which meet the requirements related to both the number of members and the variety of industry sectors covered, participate under Ustawa o Trójstronnej Komisji ds. SpołecznoGospodarczych i wojewódzkich komisjach dialogu społecznego z dnia 6 lipca 2001 [the Act on the Tripartite Commission for Socio-Economic Matters and Voivodship Commissions of Social Dialogue from 6 July 2001], (Dz.U. 2001, Nr 100, poz. 1080) in the tripartite commission to decide about the framework of working conditions.

${ }^{23}$ Kohl (n 2) 3. 
statutory minimum wage versus non-statutory minimum wages is left out of its remit; however, it needs to be noted that the statutory regulation of working conditions may reduce the importance of trade unions ${ }^{24}$ in shaping working conditions and it may cause a vicious circle to appear: weak and ineffective trade unions are losing the support of employees who, conscious of their weakness, do not call on them for protection. On the other hand, trade unions lack enough wide support of employees to win a better negotiating position within collective bargaining and industrial action. As a consequence, the weak legal position of trade unions in the process of collective bargaining seems to be an important reason of their current crisis.

\section{Bargaining policy}

In Central and Eastern European countries a bargaining policy does not exist, or it takes the form of least flawed sectoral negotiating structures e.g. centralised collective agreements for the whole industry. The collective bargaining coverage rate in Poland in 2008 was $14.4 \%$, in Estonia $11.3 \%$ in 2007, in Latvia $34.7 \%$ in 2007, in Hungary $35.5 \%$ in 2007, in the Slovak Republic $24.5 \%$ in 2007 , and in Romania $82.5 \%$ in 2006. To compare the collective bargaining coverage rate in Western European countries, in Spain it was $68.6 \%$ in 2006 , in Italy $98.2 \%$ in 2004 , and in Germany $35.8 \%$ in 2006.25

There are several aspects to this situation. In Central and Eastern Europe, collective negotiations are dealt mainly at the company level - in contrast to the usual procedures in Western Europe. ${ }^{26}$ It is a feature also characteristic of Polish industrial relations where the most important competences of trade unions are related mostly to the level of the enterprise. In the case of multi-enterprise trade unions and confederations like NSZZ Solidarność, it is not the larger unions themselves who are responsible for any actions, but the internal, enterprise-based unions. An enterprise-based trade union in Poland has exclusive right to conclude collective agreements with a single employer and cannot transfer this competence to a multi-enterprise trade union. ${ }^{27}$ This monopoly refers also to other collective agreements e.g. spending social benefit funds, consultation and giving consent in individual matters such as the consultation of termination of employment contracts, representation of collective rights and interests of employees, cooperation with labour inspection etc. Also, the guarantees of trade union independence and the protection of employment relations of trade unionists are linked to the company-level bodies. Among other things, it is possible to indicate the employer's obligation to provide to the trade union the premises and technical

\footnotetext{
${ }^{24}$ See the case of Germany and Sweden in: Damian Grimshaw, Gerhard Bosch, 'The intersections between minimum wage and collective bargaining institutions' in Damian Grimshaw (ed) Minimum Wages, Pay Equity and Comparative Industrial Relations (London: Routledge, 2013) 6-8.

${ }^{25}$ Susan Hayter, Social Dialogue Indicators, Trade union density and collective bargaining coverage International Statistical Inquiry 2008-2009 (Geneva: International Labour Organisation 2009) 10-14.

26 www.worker-participation.ed/National-Industrial-Relations/Countries (Access: 30 June 2014).

27 Zbigniew Hajn, 'Collective Labour Agreement and Contracts of Employment in Polish Labour Law' in Michał Seweryński (ed), Collective Agreements and Individual Contracts of Employment (The Hague/London/New York: Wolters Kluwer, 2003) 201.
} 
facilities necessary for union activities under the conditions regulated in the agreement (Art. 33 TUA). According to Article 32 TUA, without the consent of the board of the enterprise the employer cannot terminate the employment relationship of representatives of trade unions with or without notice. The same procedure of getting the consent of the board of the workplace trade union is required in the case of unilateral changing of their working conditions. The TUA oversees the detailed rules according to which the employment relationships of the representatives of trade unions are protected. ${ }^{28}$ Moreover, the board of the workplace-based trade union may request a release from performing work with the right of remuneration. The number of representatives of trade unions released from performing work is dependent on the number of members of the workplace-based trade union or the number of members employed in the establishment. ${ }^{29}$ Apart from that, an employee has the right to be released from work, with the retained right of remuneration for the time required to perform a casual activity resulting from their union function, if such an activity cannot be performed during their free time (Art. 32 TUA). The only competence of the multi-enterprise trade union is the right to run the collective bargaining at multi-enterprise level.

As a consequence, trade unions are not interested in negotiating collective agreements at the multi-enterprise level if collective bargaining is possible only where there is a local union organisation in the company. If a multi-enterprise trade union wants to exercise all trade union rights, it needs to create its own internal units in the form of workplace-based trade unions present in acting in different enterprises. According to Article 15 TUA a legal person can have trade unions as well as their internal entities if the statue has prescribed that. Indeed, in Poland, inside one legal person there are other entities with separate legal personalities and responsibilities. ${ }^{30}$ This regulation clearly affects industrial relations: a workplace-based trade union as a legal

\footnotetext{
${ }^{28}$ Article 32 TUA: "Without the consent of the management board of the establishment's trade union organisation, the employer cannot: 1) terminate the employment relationship either with or without notice with a member of the management board of the establishment's trade union organisation referred to by name in the management board resolution, or another employee who is a member of the establishment's trade union organisation entitled to represent the organisation before an employer or authority, or an individual who performs activities in the area of the labour law on behalf of the employer, 2) unilaterally change the work or pay conditions to the detriment of the employee referred to in an item - unless this is allowed by separate provisions".

${ }^{29}$ Article 31 TUA: " 1 . The right to be released from the obligation to perform work for the term of office on the management board of an establishment's trade union organisation is granted: 1) partially, to one employee in a monthly number of hours equal to the number of members employed in the work establishment, if their number is below 150,2) to one employee, if the trade union has from 150 to 500 members employed in the work establishment, 3) two employees, if the trade union has from 501 to 1000 members employed in the work establishment (... $)^{\text {" }, ~ 3) ~ A n ~ e m p l o y e e ~ h a s ~ t h e ~ r i g h t ~ t o ~ b e ~ r e l e a s e d ~ f r o m ~ w o r k ~ w h i l e ~}$ retaining the right to remuneration for the time required to perform a casual activity resulting from the office held in the trade union if such an activity cannot be performed during free time".

${ }^{30}$ Piotr Grzebyk, 'Liability in Damages for Strike in the Polish Labour Law' in Derechos de Negociación Colectiva ante una Economía Globalizada, X Congreso Europeo de Derecho del Trabajo y de la Seguridad Social (Chile, Asociacíon Española de Derecho del Trabajo y de la $\quad$ Seguridad Social $\quad$ 2011) http://aedtss.com/images/stories/documentos/congresoeuropecomunicaciones/2/208grzebyk .pdf
} 
person acts through its agencies but the many collective labour rights of a multi-enterprise trade union can be exercised only through workplace-based trade unions. ${ }^{31}$ In effect, Polish regulations have forced trade unions to decentralize their structure, which violates Article 2 and Article 3 of the International Labour Organization Convention No.87 on Freedom of Association and Protection of the Right to Organize, ratified by Poland. ${ }^{32}$ The provisions which adapt Articles 2 and 3 of ILO Convention No. 87 are Articles 1 and 9 TUA according to which a trade union is a self-governing organization. ${ }^{33}$ The point is that if a trade union cannot represent the rights and interests of employees without its internal structures in the form of workplace-based trade unions, it is deprived of the free choice of its internal structure and the possibility of flexible adaptation to socio-economic changes. ${ }^{34}$

The situation became complicated because of the previously mentioned statutory procedure of establishing and recognizing trade unions at the workplace level with a threshold of 10 persons, difficult to meet in the SMEs which dominate the Polish economy. Inadequate union presence has serious repercussions - only a limited number of employees are covered by collective agreements. The statistics show a $14.4 \%$ collective bargaining coverage rate and $12 \%$ union density rate. The difference is an effect of the legal framework that the workplace-based collective agreement is established for all employees of one employer, instead of only for the members of the trade union which negotiated the agreement. According to Article 7(1) TUA, trade unions represent the rights and collective interests of all employees regardless of their trade union membership. Therefore, a union may act in the name of all employees even without the real support of the majority of the

\footnotetext{
${ }^{31}$ Grzebyk (n 30) 5.

${ }^{32}$ Zbigniew Hajn, 'Ustawowy model organizacji polskiego ruchu związkowego i jego wpływ na zbiorowe stosunki pracy' [Statutory model of organisation of the Polish union movement and its impact on collective employment relationships] in Maria Matey-Tyrowicz, Lesław Nowacki, Barbara Wagner (eds) Prawo pracy a wyzwania XXI-go wieku [Employment law and the challenges of the XXIst century] (Warszawa, Biuro Rzecznika Praw Obywatelskich, 2002) 437. Opposing view: Jerzy Wratny, 'Prawne aspekty działalności związków zawodowych' [Legal aspects of trade union's activity] in Jerzy Wratny, Marek Bednarski (eds) Zwiazki zawodowe a niezwiazkowe przedstawicielstwa pracownicze $w$ gospodarcze posttransformacyjnej [Trade unions and non-union representatives of employees in the post transformational economy] (Warszawa: Instytut Pracy i Spraw Socialnych, 2010) 50-52. See: Article 2 of the ILO Convention No. 87: "Workers and employers, without distinction whatsoever, shall have the right to establish and, subject only to the rules of the organization concerned, to join organizations of their own choosing without previous authorization"; Article 3(1) of the ILO Convention No. 87 "Workers' and employers' organizations shall have the right to draw up their constitutions and rules, to elect their representatives in full freedom, to organize their administration and activities and to formulate their programmes". ${ }^{33}$ Article 1 TUA: " 1 . A trade union is a voluntary and self-governing organisation of working people, founded to defend their rights, as well as occupational and social interests. 2. In pursuing its statutory activities, a trade union is independent from employers, state administration, local government, and other organisations. 3. State and local government authorities, as well as employers, are obliged to treat all trade unions equally“. Article 9 TUA: "Statutes and trade union resolutions freely determine the organisational structures of trade unions. Only the statutory authorities of trade union structures with legal personality may contract property obligations".

${ }^{34}$ Hajn (n 32) 437; Grzebyk (30) 79.
} 
employees. ${ }^{35}$ If only one trade union exists in the workplace it conducts collective bargaining for all the workers from the company.

Article 7(1) TUA provides a solution to overcoming the low rate of collective bargaining when the trade union operates at workplace level. However, it does not resolve the problem of other sectors of industry without union movement. It also causes some problems if more than one trade union operates within a company. If there are more trade unions they can set up a joint union representation or they can act independently, possibly leading to competition between the trade unions. To overcome disagreements between trade unions unwilling to compromise on presenting a single opinion in negotiations with an employer, the employer can cooperate only with the 'representative' trade union. According to Article 241(25) of the Polish Labour Code, a representative workplace-based trade union is one which covers at least $10 \%$ of all the employees in one company or $7 \%$ if the workplace-based trade union is a part of a multi-enterprise trade union. If none of these requirements is met the representative is the enterprise-based trade union which covers the highest number of employees in one enterprise. The latter regulation should be considered as being a positive way to avoid blocking the collective bargaining negotiations by the smallest and most radical trade unions.

As a result of the low level of unionization the position of employees varies depending on whether a trade union operates in their workplace and whether they are covered by a collective agreement. Indeed, the employees employed in the enterprises where a trade union exists are in a privileged situation in comparison with others. In that situation the question arises regarding the possibility of exceeding concluded collective agreements for employees who are not yet covered by collective agreements.

With some exceptions, e.g. Slovakia, where exceeding a collective agreement can be made only through the decision of the labour minister, ${ }^{36}$ CCE countries provide two methods of exceeding collective agreements voluntary procedure or declaring the collective agreement as being generally binding. The former means the possibility of covering the employees of another employer through a collective agreement agreed between different social partners. According to Article 241(10) of the Polish Labour Code, parties who are entitled to conclude an agreement may enter into an arrangement on the application of all or any part of an agreement to which they are not parties. The arrangement requires registration within the same procedure as the collective agreement to which is applied, because the provisions relating to the agreement apply according to the arrangement. It means that the only representative of employees entitled to conclude the arrangement on the application of an agreement is a trade union - the same as in the case of concluding a collective agreement. This is an important way to shorten the lengthy negotiation period of collective agreements through applying an agreement negotiated by social partners from another enterprise, although mainly from the same industry sector. However, to conclude the agreement on applying the collective agreement established by other social

\footnotetext{
${ }^{35}$ Grzebyk (n 30) 82.

${ }^{36}$ Peter Kerckhofs, 'Extension of collective bargaining agreements in the EU' (Dublin: European Foundation for the Improvement of Living and Working Conditions, 2011)1-14, 13.
} 
partners, Article 241(10) of the Polish Labour Code requires trade unions to be involved. Thus, it does not resolve the problem of low collective agreement coverage in the face of low unionization.

From this point of view the procedure of declaring the collective agreement as generally binding seems more hopeful. In the framework of this procedure, sectoral agreements are negotiated bilaterally, including nonmembers of employers' associations and trade unions respectively, after which they are declared generally binding by the Minister for Labour. It plays a crucial role in Western Europe ${ }^{37}$ to balance low levels of unionization; however, it is underdeveloped or largely non-existent in Central and Eastern Europe. ${ }^{38}$ In fact, the extension of collective bargaining agreements appears to be widespread in all the CEE countries. However, regulations are not applied in all the countries. ${ }^{39}$ The procedure of declaring the collective agreement as generally binding is the most important in Romania where, as a result of this procedure, the coverage rate of collective agreements is close to $100 \%$. It has a value also in Slovenia, Hungary, the Czech and Slovak Republics, ${ }^{40}$ but still not in e.g. Bulgaria, where despite 16 applications from branch-level social partners the labour minister has not applied this procedure, nor in Lithuania where, although a collective agreement can be accepted by the decision of the labour minister on the demand of one social partner organisation, it has never been used.

In the case of Poland, the Labour Code provides this type of possibility in Article 241(18) according to which, under the joint request of an employers ${ }^{6}$ association and multi-enterprise trade unions that concluded a multi-enterprise agreement, the labour minister may, if necessary for important social interests, establish an executive regulation extending the scope of the application of a multi-enterprise agreement, or parts of it, to employees who are employed by an employer not covered by any multienterprise agreement but conducting the same business activity, or a business activity similar to the activity of employees covered by this agreement, established on the basis of separate law provisions concerning classification of business activity, having consulted this employer or an employers' association chosen by him, and an enterprise trade union, if there is one at the employer. Article 241(18) of the Labour Code restricts the application of the multi-enterprise agreement to be extended until an employer is covered by another multi-enterprise agreement. Although Polish labour law allows the regulation of some collective agreements to be extended, it is has never been used because multi-employer agreements are very rare in Poland. Thus, that regulation has no practical importance to bargaining policy in Poland.

The acceding procedure would seem to be a good solution to the problem of weak and varied collective bargaining policies, to increase employees' interest in trade unions and to strengthen their position in workplaces. Despite the importance of the decision of the Minister for Labour on allowing collective agreements on all employees of an industrial sector, it

\footnotetext{
${ }^{37}$ However, in six EU Member States there is no legal procedure for extending agreements Cyprus, Denmark, Italy, Malta, Sweden and the UK.

${ }^{38} \mathrm{Kohl}$ (n 2) 10.

${ }^{39}$ Kerckhofs (n 36) 13.

40 ibid 4.
} 
still requires a collective agreement at the multi-enterprise level and that it supported by a significant number of employees. Therefore, there is a vicious circle in relation to the enterprise-based model of collective bargaining in many CEE countries e.g. Poland, Lithuania or Hungary that simply accepting the collective agreement cannot overcome.

\section{Towards non-union representations?}

Given the large number of "non-union" companies (in Poland it is in the order of $80 \%$ in total) and even in parts of non-union sectors (which also lack employers' associations), the essential conditions for collective bargaining and bilateral wage settlements are missing. Moreover the phenomenon of trade unions losing public support seems to be ever greater. Trade unions do not look as interesting to young people, reducing their chances for development. ${ }^{41}$ What is more, the trend of organising informal groups, by using the Internet, to resolve single matters has appeared e.g. the protest in Poland in relation to changes in the rights of employees in relation to being a parent. ${ }^{42}$ It raises the question as to whether some form of workplace representation other than trade unions might be a solution to the low level of unionisation.

In Western Europe the number of employees covered by workers' representatives is double in comparison to union membership. In France, Austria, Belgium or Germany, between $50 \%$ and $70 \%$ of employees are represented by some form of workers' representative. However, in Eastern and Central Europe works councils are less popular than in Western European countries. The situation is best in Hungary, Slovenia and Croatia where the model of dual representation by trade unions and work councils came into force at the beginning of the 1990s (Hungary in 1992, Slovenia in 1993 and Croatia in 1996). Works councils were understood there as a means to reinforce trade unions and to justify their presence. However, such an approach to works councils might be seen as unique. In other CEE countries such as the Czech Republic, Poland and the Baltic countries, the traditional concept of uniform representation of workers' interests at company level by trade unions became the basis for regarding works councils as competitors and thus they opposed any governmental initiatives to make changes in this domain.

Insufficient union presence in enterprises caused these countries to revise their legal regulations. Due to dwindling union membership, these CEE countries have gradually abandoned the monopoly position of trade unions by law to introduce the works councils as an alternative to trade unions (the Czech Republic from 2001, Lithuania from 2003 and implemented in 2005). Others, like Slovakia, Bulgaria and Estonia, prescribed dual representation: trade unions and works councils (Slovakia in 2003, Bulgaria in 2006 and Estonia in 2007).

\footnotetext{
${ }^{41}$ According to research by CBOS (Centre for Public Opinion Research in Poland) from May 2013 the average age of members of trade union is 45 while the average age of employees is 40 .

${ }^{42}$ Monika Latos-Miłkowska, 'Pozazwiązkowe przedstawicielstwa pracownicze. Stan obecny i perspektywy rozwoju' [Non-union representation of employees. Current state and development prospects] in Jakub Stelina (ed), Zakładowy dialog społeczny [Enterprise-based social dialogue] (Warszawa: Woters Kluwer, 2014) 95-111, 107.
} 
In Poland an alternative model exists. It means that where there is no trade union, under some conditions non-union representation can appear. Indeed, non-union representation has a long history in Poland. Going back, it can include the autonomy of state-enterprises or social labour inspection. However, the legal regulations of these institutions came into force during communism ${ }^{43}$ and so they are of almost no practical importance today. The former has lost its importance because State-owned enterprises are very rare in Poland nowadays, while the latter because the election of a social labour inspector is organised by company-based trade unions, and the low level of unionisation is not favourable for following this procedure. Besides these, there are others introduced into Polish legal regulation more recently, mainly under the pressure of European law e.g. European employees' councils. ${ }^{44}$ The Polish Labour Code also lays out several provisions regarding the representatives of employees chosen in the standard manner adopted by the employer (e.g. Article 9(1) of the Labour Code). ${ }^{45}$ Despite these numerous non-union representatives who are rooted in the legal system, Poland in fact ended the monopoly of trade unions in 2006 when Polish legal regulations were adapted to the EU Directive establishing a general framework for informing and consulting employees (2002/14/EC) and the Act on Informing and Consulting Employees of 7 April 2006 came into force. ${ }^{46}$ Taking into account the weakening trade unions, the question arises of whether non-union representatives could replace trade unions in running the social dialogue to negotiate working conditions. It is an important question, as in many enterprises they are the only employee representatives.

In Poland, different forms of employee representation can co-exist in the workplace in parallel and independent ways if their competences do not overlap e.g. European employee councils and works councils, which work at different levels. However, some forms of representation which have similar competences function at the same level of a company, as in the case of the two most important forms of workers' representations i.e. works councils and representatives of employees chosen in the standard manner adopted by the employer. In such a situation the employer needs to consult the same issues multiple times at the same level of a company, which can put in doubt the seriousness of the consultation procedure, especially if the opinions on the

\footnotetext{
${ }^{43}$ Ustawa o samorządzie załogi przedsiębiorstwa państwowego z dnia 25 września 1981 [Act on Autonomy of Employees of State-owned Enterprise of 25 September 1981], Dz.U. 1981, No 24, item 123; Ustawa o społecznej inspekcji pracy z dnia 24 lipca 1983 [Act on Social Labour Inspection of 24 July 1983], Dz.U. 1983, No 35, item 163.

${ }^{44}$ Ustawa o europejskich radach zakładowych z dnia 5 kwietnia 2002 [Act on European Employees' Councils of 5 April 2002], Dz.U. 2002, No 62, item 556.

45 Article 9(1) $\S 1$ : If it is by the financial situation of an employer, agreements can be concluded suspending the application of all or part of the provisions of labour law determining the rights and duties of the parties to an employment relationship; this does not apply to the provisions of the Labour Code and the provisions of other laws and subordinate legislation. $\S 2$ The agreements referred to in $\S 1$ are concluded by an employer and a trade union representing the employees; if no such organisation is operating in the enterprise, it is the employer and representatives of the employees chosen in the standard manner by the employer that conclude the agreement".

${ }^{46}$ Ustawa o informowaniu pracowników i przeprowadzaniu z nimi konsultacji z dnia 7 kwietnia 2006 [Act on Informing and Consulting Employees of 7 April 2006], Dz.U. 2006, No 79, item 550.
} 
same matter given by these representations are different. ${ }^{47}$ In the end, instead of strengthening employees' representation and enhancing their participation in the management of a company it may weaken them, especially if the employer pits one representative against another. ${ }^{48}$

The social trust regarding the effectiveness of these types of worker representations also needs to be examined. Works councils are mandatory if there are more than 50 employees and there is no trade union representation. However, the statistical data shows that in 2008 (two years after the Act came into force) in Poland there were 2580 enterprise where works councils were in operation. In 2013 the number of registered councils had decreased by about 50\%, leaving only 1373 companies where works councils were established. This is despite the fact that in the industrial sector there were 8720 employers who met the requirements to create a works council. This form of representation has not met with the interest of employees. The main reason for the situation seems to be the complicated procedure of establishing the council, with the mandatory application of employees as well as the thresholds to announce the candidates to the council (thresholds of 10 or 20 people) which appears to be too high for the Polish working environment. It appears that employees are not interested in establishing this form of participation probably also because of the scope of its remit. ${ }^{49}$ Moreover, the employees' knowledge of the legal position of works councils and their members appears to be low. Even though, under Polish law, members of works councils enjoy the same legal protection of stability of employment as members of the board of a trade union, employees are afraid to put themselves forward to be a candidate for the works council so as not to lose their job as a consequence of their activities as a representative. As a consequence, the goal of establishing employee representation in enterprises where trade unions do not operate has not been met.

In this situation it would be difficult to hope for success in getting representation of employees' rights and interests by these representatives chosen in the standard manner adopted by the employer. They are chosen ad hoc in situations where trade unions do not exist in an enterprise and the legal provisions require the participation of a social partner e.g. the previously mentioned Article 9(1) of the Polish Labour Code. On the one hand, introducing elements of social dialogue where there is no trade union needs to be seen as a positive step; however, the quality of this dialogue is doubtful. The idea of social dialogue is based on the principle of the equality of its actors. Taking into account the lack of increased job protection, these representatives seem to be too weak to run a dialogue with their employer to defend the rights and interests of their fellow employees. ${ }^{50}$

To summarize, introducing elements of social dialogue where there is no trade union needs to be seen as a positive step; however, the quality of this dialogue is doubtful. The idea of social dialogue is based on the principle of the equality of its actors. Non-union representatives seem to be too weak in terms of their competences and the legal stability of their labour relationships to run a dialogue with their employer based on the principle of equality.

\footnotetext{
${ }^{47}$ Latos-Miłkowska (n 42) 98.

48 ibid 99.

49 ibid 104

${ }^{50}$ Latos-Miłkowska (n 42) 107.
} 
Additionally, they are not prepared enough or supported by their fellow employees to effectively substitute trade unions in their competences.

\section{CONCLUSIONS}

Although Central and Eastern European countries have shared a similar history in the recent past, they took different approaches to changing their general framework and adapting to current challenges. ${ }^{51}$ Regardless of the profile of collective labour relations, the feature characteristic of the labour markets in CEE countries is the decentralization of trade unions and lack of support by employees for the union movement. Common is the vicious circle related to the weak legal position of trade unions where the employees do not rely on trade unions to defend their rights and interests because of how weak they are, while on the other hand trade unions are not supported enough by the employees to strengthen their legal position.

The current state of trade unions is caused by several factors. To mention only a few, we firstly need to refer to the weakness of trade unions when negotiating with the state on the most essential working conditions. The problem also stems from applying the enterprise-based model of collective bargaining in CEE countries, but with some exceptions. In this model, multienterprise relations are based on the company-based system too. In effect, collective agreements take into account only the interests of workers from one or a few employers, regardless of the situation and interests of employees from the same sector of industry. ${ }^{52}$ This leads to, among other things, the varied legal situations of employees, regarding whether they work at enterprises where trade unions operate and - potentially - whether a collective agreement can provide them with better than statutory working conditions. The relocation of enterprise-based trade unions to mostly ex-state owned enterprises has resulted in a situation where other sectors of industry, where there are no ex-state owned enterprises, are free from collective agreements. ${ }^{53}$ Moreover, there is no balance for low unionization. The statistical data on exceeding collective agreement seem to show that the procedure is ineffective.

The weakness of trade unions refers also to the excessive concentration of competences of trade unions at the enterprise level, which inevitably causes competition between trade unions that leads to a further weakening of their position. This concentration of trade unions' competences at the plant level has resulted in their lack of interest in transferring to the multi-enterprise level. As a result, it affects the structures of employers' associations. Without a social partner at the upper-enterprise level they are also not interested in establishing their structures there. To some extent employers also prefer to resolve labour disputes within the company instead

\footnotetext{
${ }^{51}$ Kohl (n 2) 4.

52 Ludwik Florek, 'Zalety i wady działalności związków zawodowych na szczeblu zakładowym' [Advantages and disadavanteges of enterprise-based acitivity of trade unions] in Zbigniew Hajn (ed), Związowe przedstawicielstwo pracowników zakładu pracy [Enterprise-based union representation of employees] (Warszawa: Wolters Kluwer, 2012) 203-214, 209.

${ }^{53}$ Grzebyk (n 30) 85.
} 
of acting outside the enterprise. Therefore that model of industrial relations seems to be accepted by both social partners. ${ }^{54}$ Thus, waiting for their suggestions for change in this aspect might be hopeless. To the grim picture it needs to be added that there are also some advantages to the enterprisebased model of collective bargaining. Enterprise-based trade unions are directly connected with the workers whose interests it defends and know better their individual situations. However, the principle of trade union pluralism and competition between trade unions in one enterprise makes their effectiveness unclear.

Taking into account the current crisis of trade unions on the one hand, and the weakness of non-union representation on other, the solution is not clear. Should non-union representation remain relatively weak because the rights and interests of workers should take precedence over trade unions? Or should non-union representation be strengthened so it can run a social dialogue with the employer as an equal partner? Without deep changes of the model of unionization it seems that trade unions will remain in crisis for a long time, despite them being the best prepared to represent the workers in their organisational and essential ways. However, the existing model of nonunion representation should be strengthened too e.g. through simplifying the procedure of establishing the works council ${ }^{55}$ to represent, in an effective way, the rights of employees from an enterprise where trade unions are missing. However, they seem to lack the social support to take the place of trade unions in exercising their functions. The lack of willingness to establish this type of workers' representation in Poland does not confirm the opinion given in the literature that the "alternative model" of either works council or trade union representation introduced in Eastern and Central Europe might reinforce potential members' impressions that works councils can achieve the same results without their having to pay membership dues. ${ }^{56}$ Thus the model of balance between trade union and non-union representation with development of both towards meeting the goal i.e. workers' solidarity in defending their rights and interests, seems to be necessary.

\section{Bibliography}

Judgment of the Polish Constitutional Tribunal of 28 September 2006, Case K 45/04, Dz.U. 2006, No 183, item 1363.

Ustawa o związkach zawodowych z dnia 23 maja 1991 r. [Trade Union Act - TUA of 23 May 1991], Dz.U. No 55, item 234.

Ustawa o Trójstronnej Komisji ds. Społeczno-Gospodarczych i wojewódzkich komisjach dialogu społecznego z dnia 6 czerwca 2001 r. [Act on the Tripartite Commission for Socio-Economic Matters and Voivodship Commissions of Social Dialogue of 6 July 2001], Dz.U. 2001, No 100, item 1080.

Konstytucja Rzeczypospolitej Polskiej z dnia 2 kwietnia 1997 r. [the Polish Constitution of 2 April 1997], Dz.U. 1997, No 78, item 483.

Ustawa o samorządzie załogi przedsiębiorstwa państwowego z dnia 25 września 1981 r. [Act on

Autonomy of Employees of State-owned Enterprise of 25 September 1981], Dz.U. 1981, No 24, item 123;

\footnotetext{
54 ibid.

${ }^{55}$ Latos-Miłkowska (n 42) 111.

${ }^{56}$ Kohl (n 2) 4.
} 
Ustawa o społecznej inspekcji pracy z dnia 24 lipca 1983 r. [Act on Social Labour Inspection of 24 July 1983], Dz.U. 1983, No 35, item 163.

Ustawa o europejskich radach zakładowych z dnia 5 kwietnia 2002 r. [Act on European Employees' Councils of 5 April 2002], Dz.U. 2002, No 62, item 556.

Ustawa o informowaniu pracowników i przeprowadzaniu z nimi konsultacji z dnia 7 kwietnia 2006 r. [Act on Informing and Consulting Employees of 7 April 2006], Dz.U. 2006, No 79, item 550.

Aczel J, 'Changes in the role of the trade union in the Hungarian printing industry. A transition from socialism to a market economy' (2005) 27/6 Employee Relations 566-580.

Florek L, 'Zalety i wady działalności związków zawodowych na szczeblu zakładowym' in Zbigniew Hajn (ed) Zwiąkowe przedstawicielstwo pracowników zakładu pracy, (Warszawa: Wolters Kluwer, 2012) 203-214.

Grimshaw D, Bosch G, 'The intersections between minimum wage and collective bargaining institutions' in Damian Grimshaw (ed), Minimum Wages, Pay Equity and Comparative Industrial Relations (London: Routledge, 2013), 6-8.

Grzebyk P, 'Liability in Damages for Strike in the Polish Labour Law' in Derechos de Negociación Colectiva ante una Economía Globalizada, X Congreso Europeo de Derecho del Trabajo y de la Seguridad Social, Asociacíon Española de Derecho del Trabajo y de la Seguridad Social http://aedtss.com/images/stories/documentos/congresoeuropecomunicaciones/2/208grzebyk .pdf.

Hajn Z, 'Representation of Employees in Collective Bargaining within the Firm in Poland' in Biruta Lewaszkiewicz-Petrykowska (ed), Presénté au XVIIe Congrés international de droit comparé (Łódź, Wydawnictwo Uniwersytetu Łódzkiego 2006).

Hajn Z, 'Collective Labour Agreement and Contracts of Employment in Polish Labour Law' in Michał Seweryński (ed) Collective Agreements and Individual Contracts of Employment, (The Hague/London/New York: Wolters Kluwer, 2003).

Hajn Z, 'Ustawowy model organizacji polskiego ruchu związkowego i jego wpływ na zbiorowe stosunki pracy' [Statutory model of organisation of Polish union movement and its impact on collective employment relationships] in Maria Matey-Tyrowicz, Lesław Nowacki, Barbara Wagner (ed) Prawo pracy a wyzwania XXI-go wieku (Warszawa, Biuro Rzecznika Praw Obywatelskich, 2002).

Hayter S, 'Social Dialogue Indicators' in Trade union density and collective bargaining coverage International Statistical Inquiry 2008-2009 (International Labour Organisation 2009).

www.worker-participation.ed/National-Industrial-Relations/Countries (Access: 30 June 2014).

Kerckhofs P, 'Extension of collective bargaining agreements in the EU' (Dublin: European Foundation for the Improvement of Living and Working Conditions, 2011).

Kohl H, 'Where Do Trade Unions Stand Today In Eastern Europe? Stock-taking After EU Enlargement' (2008) 5 Friedrich Ebert Stiftung, International Trade Union Cooperation, Briefing Paper.

Latos-Miłkowska L, 'Pozazwiązkowe przedstawicielstwa pracownicze. Stan obecny i perspektywy rozwoju' [Non-union representation of employees. Current state and development prospects] in Jakkub Stelina (ed), Zakładowy dialog społeczny (Warszawa: Woters Kluwer, 2014).

Pliszkiewicz M, 'The Development of Industrial Relations in Central and Eastern Europe' in M Seweryński (ed), Polish Labour Law and Collective Labour Relations in the Period of Transformation (Warsaw: Ministry of Labour and Social Policy, 1995).

Seweryński M, 'Toward a New Codification of Polish Labour Law' (2004) 26 Comparative Labour Law and Policy Journal.

Seweryński M, 'Trade Unions in the Post-Communist Countries: Regulations, Problems and Prospects' (Winter 1995) 16 Comparative Labour Law Journal.

Wratny J, 'Prawne aspekty działalności związków zawodowych' in J Wratny, M Bednarski (eds), Zwiąki zawodowe a niezwiąkowe przedstawicielstwa pracownicze $w$ gospodarcze posttransformacyjnej (Warszawa: Instytut Pracy i Spraw Socialnych, 2010). 
www.worker-participation.eu/National-Industrial-Relations/Across-Europe/TradeUnions2 (Access: 30 of June 2014).

www. eurofound.europa.eu/eiro/2013/10/articles/lt310039.htm (Access: 28 July 2014). 